KaZimierz BARAN

\title{
$Z$ dziejów procesów o zbrodnię stanu Sprawa Throckmortona (1554 r.) w Anglii epoki Tudorów
}

\author{
Aus der Geschichte der Prozesse wegen Staatsverbrechen \\ Throckmortons Fall (1554) in England der Tudorzeit
}

1. Typ analizowanego procesu. Jego osobliwość. 2. Angielski proces karny wobec procesu kontynentalnego: skontrastowanie zasad proceduralnych. 3. Analiza przebiegu procesu Throckmortona (w szczególności - reakcja oskarżonego na indictement, jego wejście w pleading i dynamika podjętej przezeń altercation, przyczyny werdyktu uniewinniającego). 4. Wnioski końcowe.

1. Der Typ analysiertes Prozesses. Seine Eigenart. 2. Englischer Strafprozess gegen kontinentalen Prozess: ein Kontrast zwischen den Verfahrensprinzipien. 3. Die Analyse des Verlaufes des Throckmortons-Prozesses (insbesondere - die Reaktion des Angeklagten auf indictement, sein Eingang in pleading und die Dynamik seiner altercation, Gründe für Freispruch). 4. Schlussfolgerungen.

1. W roku 1554 miał miejsce w londyńskim Guildhall, przeprowadzony przez specjalnie do tego celu powolaną komisję sądową, proces Nicholasa Throckmortona. Throckmorton, dyplomata i posel do Izby Gmin, sądzony był za współudzial w zorganizowaniu nieudanej rebelii pod wodzą Whyatta, mającej na celu obalenie Marii Tudor i wyniesienie na tron jej przyrodniej siostry - Elżbiety. Spiskowcy chcieli zapobiec tym sposobem rysującemu się na horyzoncie politycznym ślubowi Marii Tudor z Filipem Hiszpańskim.

Throckmorton byl wojującym protestantem, co ułatwia zrozumienie motywów jego postępowania. Nieco trudniej pojąć motywy Whyatta, który był katolikiem, pałał jednak nienawiścią do Hiszpanów.

Rebelię wzniecono w hrabstwie Kent, skąd spiskowcy przemieścili się $w$ kierunku Londynu, mając $w$ zamyśle zajęcie Tower. Powstanie jednak rychło upadło. Whyatt, który nie popisał się zdolnościami przywódczymi, został pojmany i po szybkim procesie stracony ${ }^{1}$. Wkrótce też rozpocząl się

1 Prócz Whyatta grupę spiskowców tworzyli m. in. Cuthbert Vaughan, James Crofts, Peter Carew czy Edward Courteney. Na temat okoliczności rebelii por. C. G. L. Du Cann, 
proces Throckmortona, oskarżonego o współudział w przygotowaniu spisku, a więc o typową high treason, zbrodnię stanu2. Osobliwością tego procesu był jego final: uniewinnienie Throckmortona przez lawę przysięgłych, mimo oczywistych dowodów winy podejrzanego. Orzekając w ten sposób, ława wykazała niezwykłą - jak na owe czasy - niezależność. Niewątpliwie jej gremium musiało się rekrutować $w$ większości z przeciwników zbliżenia między Anglią i Hiszpanią. Sympatie przysięgłych układały się więc po stronie Throckmortona. Pretekst do orzeczenia ,not guilty” dostarczyl im zaś sam oskarżony, z niezwykłą zręcznością przeprowadzający swą obronę na publicznej rozprawie. Wcześniej, w przypadku oskarżenia o high treason, sztuka ta udała się jedynie lordowi Dacre, którego sądziła Izba Parów w czasach Henryka VIII. Dacre przeprowadził swą obronę - jak mówiono - „manfully, wittingly and directly”, dzięki czemu zostal przez parów uniewinniony. Dacre umiejętnie podważyl zaufanie jury do świadków, którymi $w$ procesie tym byli wzbudzający odruchową nieufność w Anglii - Szkoci. Oskarżony lord emfatycznie zbijal każde ich twierdzenie. Przypuszcza się jednak, że wówczas Korona wyraziła cichą aprobatę na uniewinnienie podsądnego ${ }^{3}$. Natomiast w przypadku Throckmortona $\mathrm{z}$ pewnością aprobaty tej nie było.

2. By zrozumieć przebieg procesu Throckmortona i możliwość zaistnienia takiego właśnie werdyktu $\mathrm{w}$ procesie politycznym, słów kilka poświęcić wypadnie przypomnieniu reguł, jakimi rządzilo się postępowanie karne toczące się wedle common law w ówczesnej Anglii. Trzeba zauważyć, iż proces polityczny, jeśli toczył się przed zwykłym sądem z zastosowaniem lawy przysiegłych, a nie na przykład przed sądami prerogatywnymi w rodzaju Sądu Wysokiej Komisji czy Izby Gwiaździstej ${ }^{4}$ - nie odbiegał zasadniczo od podstawowego modelu postępowania karnego właściwego dla sprawców sądzonych za przestępstwa pospolite. Różnica tkwić mogła jedynie w skrupulatniej zbieranym materiale dowodowym. W procesie politycznym Korona zatrudniala $w$ tym celu cały sztab counsellors at the Bar, a więc wytrawnych

\footnotetext{
English treason trials, London 1964, s. 67; także The dictionary of national biography, ed. L. Stephen, S. Lee, Oxford University Press, reprint, 1917 (1950), vol. XIX, s. 810-814.

${ }^{2} \mathrm{Na}$ temat procesu Throckmortona por. Cobbett's complete collection of state trials and proceedings for high treason and other crimes and midemeanours, London 1816, vol. I [cyt. dalej: State Trials], s. 870-902; także C. G. L. Du Cann, English treason..., s. 66-83.

${ }^{3}$ Por. C. G. L. Du C a n n, English treason..., s. 24-25, 66.

${ }^{4} \mathrm{~W}$ przypadku Throckmortona inne rozsądzenie sprawy nie wchodziło zresztą $\mathrm{w}$ grę. Tylko bowiem, gdyby czyn jego zakwalifikowano na dużo niższym poziomie, jako misdemeanour, - można by go poddać jurysdykcji Izby Gwiaździstej. Na temat spraw rozpatrywanych przez ten sąd por. K. B a r a n, Strony procesowe przed angielskimi sqdami karnymi doby Tudorów i wczesnych Stuartów (do roku 1640), Uniw. Jagiell., Kraków 1994, s. 51 i n.
} 
jurystów, którzy przygotowywali oskarżycielskie akta sprawy, odbierając zawczasu na piśmie zeznania świadków, często potem - wbrew uzusowi stosowanemu $w$ przestępstwach pospolitych - jedynie odczytywane przed sądem, bez ponownego słuchania autorów owych zeznań w sytuacji stawiania ich face to face $\mathrm{z}$ oskarżonymi na sali sądowej. Tylko świadków będących szczególnie mocnym atutem oskarżenia - counsellors at the Bar - doprowadzali na rozprawę. Chodziło bowiem o to, by przysięgli - którzy w Anglii orzekali wyłącznie na podstawie wydarzeń, które rozegrały się na ich oczach w trakcie publicznej rozprawy - uformowali swój werdykt w pożądanym przez komisję śledczą kierunku.

W trakcie rozprawy rutynowym zadaniem jurystów-oskarżycieli było zadawanie podsądnemu pytań (owo oskarżycielskie: How sayth thou...), które stawiane punkt po punkcie na publicznej rozprawie, miały go zmusić do thumaczenia się $\mathrm{z}$ zarzutów ${ }^{5}$.

Odbiegający nieco od tego schematu proces o przestepstwa pospolite był bardziej fair wobec oskarżonego i stąd zapadający w jego finale werdykt „,not guilty" nie byłby rzeczą tak zdumiewającą. Statystyka wskazuje, iż w Anglii między XVI a XVIII stuleciem liczba uniewinnień orzekanych przez lawę w sprawach pospolitych wahała się w granicach od 25 do $50 \%{ }^{6}$. Przede wszystkim w przypadku oskarżenia o przestępstwa pospolite - śledztwo prowadzone przez sędziego pokoju na podstawie tzw. Statutów Mariańskich (z połowy XVI w.) pozostawiało wiele do życzenia. Jego wymogi stanowiły bezsprzeczny kontrast $\mathrm{z}$ wymogami stawianymi sędziemu inkwirentowi w kontynentalnej procedurze wedle Constitutio Criminalis Carolina z $1532 \mathrm{r}$. W Anglii zadaniem sędziego pokoju nie było zebranie wystarczających do skazania dowodów. Nie byl bowiem sędzia wiązany formalną teorią dowodową na wzór tej, którą stosowano na dużych obszarach ówczesnej Europy. Prowadzący śledztwo angielski justice of the peace mial świadomość, iż przysięgli mogą skazać, opierając się na dowodach mających naturę wyłącznie poszlakową, mogą z kolei wykluczyć winę przy istnieniu nader silnych jej dowodów, mogą wreszcie - motywowani względami społecznymi i działając często za cichą aprobatą sądu - obniżyć, wbrew faktom, kwalifikację czynu, określając na przykład wartość ukradzionego przez sprawcę przedmiotu na bardzo niskim poziomie ${ }^{7}$. Werdykt, z jakim powracali wówczas $\mathrm{z}$ narady, brzmiał: „winny kradzieży, lecz poniżej 40 szylingów”. Było to sprzeczne $z$ prawdą, lecz ratowało gardło podsądnemu, który w takich razach mógł

${ }^{5}$ State trials 1816, I, s. 874; por. też komentarz C. G. L. Du Ca n n a, English treason..., s. 72 i n.

${ }^{6}$ I. A. S h a r p e, Crime in early modern England 1550-1750, London, New York 1987, s. 81-82;

I. H. B a ke r, Criminal courts and procedure at common law 1550-1800, [w:] Crime in England 1500-1800, ed. J. S. Cockburn, London 1977, s. 23.

${ }^{7}$ K. B a r a n, Powstanie i ewolucja angielskiej lawy przysieglych (między średniowieczem a XIX stuleciem), [w:] Szkice z dziejów ustroju i prawa, Wyd. Uniw. Jagiell., Kraków 1997, s. 39-58. 
zażądać podania mu Biblii i odczytać zeń tzw. „wiersz gardłowy” (neck verse). Jeśli był analfabetą, uczył się go na pamięć. Od tego momentu traktowany byl jako clericus i po otrzymaniu niewielkich kar pokutnych oraz napiętnowaniu (tak, by po raz drugi nie mógł skorzystać $z$ „dobrodziejstwa kleru") wychodził na wolność ${ }^{8}$.

Świadom tych okoliczności, w szczególności zaś dużego zasięu władzy dyskrecjonalnej pozostającej $w$ gestii przysięłych, sędzia pokoju troszczył się nie tyle o osiągnięcie jakiegoś optimum dowodowego, które zaprezentowałby na rozprawie, lecz raczej jedynie o zabezpieczenie stawiennictwa tych świadków oskarżenia, których udało mu się ustalić. W tym celu obligowal ich pod bardzo wysokimi grzywnami do jawienia się na najbliższej sesji kwartalnej bądź assyzalnej. Ze swych czynności śledczych sporządzal tylko notatkę, która przeszła do historii pod nazwą "raportu mariańskiego"9. Odczytywano go na początku rozprawy i następnie usuwano $\mathrm{z}$ akt. Przysięgli czerpali zeń bardzo ogólnikową wiedzę o sprawie, którą za chwilę mieli rozpatrywać. Do raportu nie przywiązywali większej wagi. Dla nich liczyło się przede wszystkim to, co sami de visu et auditu mogli stwierdzić na podstawie spektaklu rozgrywającej się przed nimi rozprawy. Było więc istotne, by nabrała ona pewnej dynamiki, obejmując cross-examination świadków, czy altercation, a więc zwarcie się oskarżonego z oskarżycielem, lecz także ze świadkami, i czasem - $\mathrm{z}$ samym sądem ${ }^{10}$. Przesunięcie $w$ tej procedurze punktu ciężkości na ustną i jawną rozprawę sprawiało, iż tortury - jako epizod spoza rozprawy głównej - nigdy nie nabrały w Anglii większego znaczenia ${ }^{11}$.

Formalnie rzecz biorąc, sprawy wyglądały podobnie w przypadku lawy orzekającej w sprawach politycznych. I tutaj dysponowala ona w zasadzie pełnią władzy dyskrecjonalnej w podejściu do sprawy. Rzeczywistość jednak przeczyła temu. Poprzez niedwuznaczny nacisk ze strony składu sądzącego Korona starała się nakłonić lawę do orzeczenia biegnącego po linii państwowej. Praktykę tę nazywano intimidation. Dodajmy zresztą, iż wobec skrupulatniej w razach takich prowadzonego śledztwa, lawie pozostawiano niejako mniej miejsca na swobodę manewru w kierunku orzeczenia contra manifestam evidentiam.

Oba procesy - tak polityczny, jak i ów mający za przedmiot przestępstwa pospolite - posługiwały się nadto $w$ interesującej nas epoce, wyłącznie świadkiem oskarżenia. Świadek obrony nie był dopuszczalny ze względu na oportunistycznie interpretowaną zasadę udowadniania oskarżonemu stawianych

\footnotetext{
${ }^{8} \mathrm{Na}$ temat dobrodziejstwa kleru por. K. B a r a n, Strony.., s. 113-114.

9 Ibidem, s. 42-45.

${ }^{10}$ Ibidem, s. 64-69, 75-92.

11 I. H. L a ng bein, Torture and the law of proof, Europe and England in the Ancien Regime, The University of Chicago and London 1977, s. $81 \mathrm{i} \mathrm{n}$.
} 
mu zarzutów beyond reasonable doubt - poza zasięgiem racjonalnie nasuwających sie wątpliwości. Skoro - argumentowano - stawiano tak wysoki wymóg dowodowi oskarżenia, obrona podsądnego stawała się rzeczą zbyteczną ${ }^{12}$.

Ową wyłączność świadka oskarżenia dobrze ilustruje tekst szesnastowiecznego jurysty Tomasza Smitha, opisujący przebieg procesu karnego w renesansowej Anglii. W wyjściowym punkcie spektaklu sądowego woźny zwracał się do audytorium charakterystyczną formułą: Jeśli ktoś może dać dowód lub powiedzieć cokolwiek przeciw [sic! K. B.] oskarżonemu, niechaj wystapi [...] Jeśli ci, których zobligowano, by stawili sie $i$ dali świadectwo, wystapiq, tedy najpierw czytane sq zeznania, które przedklada sedzia pokoju [chodzi tu więc o raport mariański - K. B.], po czym przestuchiwany jest ten (jeśli jest obecny), którego poszkodowano, by stwierdzić, co potrafi powiedzieć po uprzednim zaprzysieżeniu, izby zeznawal prawde. Potem sluchany jest konstabl oraz tylu innych, ilu bylo obecnych przy pojmaniu zloczyńcy, a $i$ dalsi, gdy moga coś powiedzieć po uprzednim zaprzysięzeniu, jeden po drugim. Po zaprzysięzeniu [świadków - K. B.] sędzia zapytuje najpierw poszkodowanego [dosłownie: obrabowanego - K. B.], czy zna on wieźnia i każe mu nań spojrzeć. Ten zaś odpowie, iż go zna, czemu więzień czasem zaprzecza [...] i tak trwaja oni przez chwile $w$ altercation, po czym mówi on [tj. poszkodowany - K. B.] wszystko, co potrafi. W podobny sposób mówiq po nim ci, którzy byli przy pojmaniu więźnia lub ci, którzy moga podać jakieś wskazówki lub znaki, które w naszym jezyku zwiemy dowodem oskarżenia. [sic! K. B.] Gdy zaś sedzia wyslucha ich dostatecznie dlugo, pyta, czy moga coś nadto dodać. Gdy ci zaprzecza, tedy zwraca sie do lawy ${ }^{13}$.

Prócz świadka obrony odmawiano także oskarżonemu możliwości poshużenia się obrońcą prawnym. Sąd mógł zgodzić się na jego udział tylko wyjątkowo i tylko on points of law, a więc w kwestiach trudnych zagadnień prawnych, lecz bez prawa wyręczania podsądnego w zadawaniu świadkom pytań krzyżowych czy przemawiania do przysięgłych.

Dodajmy natomiast, iż $w$ epoce tej rysować się już stopniowo poczęla w procedurze karnej Anglii jedna z najbardziej poczesnych reguł wykluczających (exclusionary rules), a więc reguł mających za zadanie eliminowanie niektórych rodzajów dowodów jako zbyt niepewnych czy wręcz zwodniczych. Regułą, o którą tu chodzi, byl zakaz posługiwania się świadkiem zwanym hearsay, czyli świadkiem $\mathrm{z}$ drugiej ręki. Hearsay przytaczal jedynie słowa świadka właściwego. Ten wszakże nie zjawiał się na sali sądowej, aby zeznać o faktach. Ponieważ zaś hearsay nie znał faktów $z$ autopsji, nie nadawal się on do tego, by go zaprzysiąc bądź poddać przesłuchaniu z zastosowaniem

${ }^{12}$ K. B a ran, Strony..., s. 59-60, 83, 93.

${ }^{13} \mathrm{Th} . \mathrm{S} \mathrm{m}$ it h, The commonwealth of England and the manner and government thereof, compiled by the Honourable Sir Thomas Smith, London 1640, s. 184-186. 
cross-examination $^{14}$. Ponieważ reguła zakazująca hearsay była $\mathrm{w}$ XVI $\mathrm{w}$. wciąż jeszcze in statu nascendi, w procesach politycznych można ją było nieraz zignorować. Dawało to upust oportunizmowi sądu. Zjawisko to dostrzec można niewątpliwie, śledząc przebieg procesu Throckmortona.

3. Na tle dotychczasowych rozważań spójrzmy obecnie na ciekawsze fragmenty analizowanego tu, osobliwego procesu. Jak wspomniano, odbył się on w londyńskim Guildhall przed specjalnie do tego celu powołaną komisją, której przewodniczył Lord Chief Justice Sir Thomas Bromley. W skład komisji weszło kilku sędziów z Queen's Bench oraz Common Pleas. Dokooptowano też kilku dygnitarzy Korony ${ }^{15}$. Proces przebiegal wedle wszystkich reguł przewidzianych w common law dla spraw karnych. Skład sądzący nie miał więc wpływu na orzeczenie o winie. Decydowala o niej lawa przysięgłych.

Przed odczytaniem indictement, czyli aktu oskarżenia, nakazano Throckmortonowi podnieść rękę (hold up thy hand). Istnial zwyczaj ponawiania potem tego żądania przed odczytaniem wyroku. Celowość żądania uzasadniano koniecznością unikania wszelkich ewentualnych pomylek, jakie mogłyby powstać po stronie więziennego konwoju co do identyfikacji skazańca. Dzięki odczytanemu publicznie indictement Throckmorton po raz pierwszy zapoznal się dokładnie $\mathrm{z}$ treścią stawianych mu zarzutów. Zgodnie z ówczesnymi regułami proceduralnymi, oskarżony przed rozprawą nie powinien mieć do indictement dostępu. Po odczytaniu mu tekstu indictement sąd skierowal do oskarżonego uświęcone tradycją pytanie tyczące winy: What sayest thou to it: Art thou guilty [...] or not guilty... ${ }^{16}$. Oskarżony $w$ odpowiedzi zobligowany byl zareagować przez tzw. pleading. Rozumiano przez nie sformalizowaną jego reakcję na postawione mu pytanie. Winien więc: w razie przyznania się do winy - zareplikować guilty, w przeciwnym zaś razie - odpowiedzieć not guilty. Były też, z rzadka, możliwe $\mathrm{i}$ inne - jak je nazywano - pleas, choćby: autrofoit acquit lub autrofoit convict w razie powolywania się przez oskarżonego przykladowo na res iudicata ${ }^{17}$. To jednak w przypadku Throckmortona w grę nie wchodziło.

${ }^{14} \mathrm{Na}$ temat hearsay por.: Stephen's Commentaries on the laws of England, vol. IV: Criminal law, ed. W. H. D. Winder, s. 182-191; także I. H. B a k e r, Criminal courts..., s. 39; D. O g g, England in the reign of James II and William III, Oxford, New York 1984, s. 102; St. Waltoś, Świadek w historii $i w$ świecie wspólczesnym. Studium prawnoporównawcze, [w:] Swiadek w procesie sqdowym, Warszawa 1985 , s. 58.

15 Por. komentarz C. G. L. Du Canna, English treason..., s. 68-69.

${ }^{16}$ Ibidem, s. 70; por. także Th. S mith, The commonwealth..., s. 180; I. H. B a k e r, Criminal courts..., s. 34 .

${ }^{17}$ W. Blackstone, Commentaries on the laws of England in four books, by Sir William Blackstone, London 1809, s. 334-337; także E. Coke, The third part of the institutes of the laws of England concerning high treason and other pleas of the Crown and criminal causes, London 1809, s. 212-214. 
Throckmorton nie chcial jednak od razu udzielić oczekiwanej od niego prostej odpowiedzi, mieszczącej się $w$ kanonie pleading. Zastrzegl się, iż najpierw pragnie wypowiedzieć kilka zdań. Po tej potyczce słownej, w której Chief Justice nazwal manewry Throckmortona gra na zwłokę (These be but delays to spend time), sklad sądzący zgodzil się na krótkie exposé podsądnego. Nie mogło być zresztą inaczej. Przekonanie, iż $w$ ramach altercation oskarżony może interweniować bezustannie $w$ bieg procesu było tak silne, iż rodziło ustępliwość sądu. Dodajmy ponadto, iż przed podjęciem pleading oskarżony miał $w$ istocie niezaprzeczalne prawo do podniesienia jednej kwestii: wskazania na jakikolwiek rzeczowy, choćby najbardziej trywialny, na przykład literowy błąd, zawarty w dopiero co odczytanym mu tekście indictement. Mógł to być na przykład za mało precyzyjny opis czynu, bądź inne drobne pomyłki tyczące okoliczności sprawy i sprawcy. Błędy takie, na zasadzie uświęconego długą tradycją zwyczaju, powodowały całkowity upadek oskarżenia.

I rzeczy takie naprawdę zdarzaly się w praktyce, jak choćby w przypadku owego mordercy, który zabił człowieka w dniu św. Piotra, co też odnotowano $\mathrm{w}$ indictement, zapominając dodać, które $\mathrm{z}$ dwóch świąt $\mathrm{w}$ roku jemu poświęconych miano na myśli. Źródła dostarczają też przykładu upadku oskarżenia w sytuacji, gdy indictement błędnie określiło społeczny status oskarżonego, nazywając go farmerem, gdy tymczasem był on yeomanem ${ }^{18}$. Uchybień tych nie dało się już usunąć. Uważano je za swoisty wentyl bezpieczeństwa, pozwalający dyskontować nadmierną, wręcz barbarzyńską czasem surowość prawa angielskiego.

Naleganie Throckmortona, iż chce być dopuszczony do głosu, lecz bez śladu spontanicznej $\mathrm{z}$ jego strony reakcji oprotestowującej indictement, wskazywało, iż chodziło mu o coś innego. Tak też było w istocie. Dopuszczony do głosu, wyglosił on bowiem do sądzącego go składu następującą tyradę: Dostojni Lordowie. Nie spieszcie sie tak w mej sprawie. Niech myśli wasze nie krążq wokól obiadu. Spożyjecie wasz posilek, gdy uczciwie zadośćuczynicie sprawiedliwości. Chrystus rzekl bowiem: „Blogosiawieni, którzy laknq i pragna sprawiedliwości' ${ }^{\prime \prime 19}$. Powściągając pośpiech sądu, Throckmorton mógł być nurtowany obawami, jakie wyobraźnia w tej epoce podsuwać mogła dorosłemu Anglikowi, mającemu na ogół za sobą jakieś doświadczenia wyniesione z uczestnictwa w kwartalnych czy assyzalnych sesjach sądowych. Sprawy $\mathrm{z}$ kategorii co najmniej felony, a więc takie, w których ważyły się losy ludzkie, były tam rozpatrywane $\mathrm{z}$ zawrotną szybkością. Nic nie stało temu na przeszkodzie wobec braku profesjonalnych jurystów wspomagających strony oraz zakazu posługiwania się świadkiem obrony. W późniejszych

18 A. Lieck, Justice and police in England, London 1929, s. 4; K. B a ra n, Strony..., s. 61

${ }^{19}$ State trials 1816, I, s. 870; por. także C. G. L. Du Can n, English treason..., s. 70-71. 
czasach ten stan rzeczy zyskał odzwierciedlenie w kaśliwym fragmencie dłuższego poematu angielskiego poety Pope'a:

The hungry judges soon the sentence sign And wretches hang, that jurymen can dine.

(Głodni sędziowie wyrok co rychlej sygnują, Łotrów do kata, przysięgłych - na obiad kierują) $)^{20}$.

Sądząc po poruszeniu, jakie wywołał Throckmorton swą wypowiedzią, musiał on trafić w czuły punkt. Sędziowie, jak choćby Earl of Shrewsbury, poczęli się zarzekać, iż $w$ służbie Królowej gotowi są zrezygnować $z$ całodziennego posiłku ${ }^{21}$. Epizod zakończył się ostatecznie wypowiedzeniem przez Throckmortona formuły not guility, co pozwoliło sądowi - w obrębie swoistego teatrum gestu i słowa tworzącego początek trial - zadać podsądnemu kolejne pytanie: How will thou be tried? (,Jak chcesz Waść, by Cię sądzono?"). Pytanie to zadawano oskarżonemu niezmiennie od XIII w., a ściślej - od chwili, gdy pod wpływem Soboru Laterańskiego IV (1215 r.) zaniechano dawnych, irracjonalnych metod dochodzenia do prawdy w procesie, porzucając zwłaszcza ordalia. Na zadane mu pytanie oskarżony winien był odpowiedzieć formulą: By God and my country (,Przez Boga i okolicę"). To ostatnie określenie oznaczało przysięgłych pochodzących $z$ jego sąsiedztwa. Odmowa wypowiedzenia formuly oznaczała brak przyzwolenia podsądnego na trial $\mathrm{z}$ użyciem lawy. Uniemożliwiało to dalsze postępowanie $w$ sprawie. Sąd mógł próbować wówczas wywrzeć na oskarżonego presję, by - jak mówiono - „zdał się on na okolicę" (put himself on the country). Stosowano $\mathrm{w}$ tym celu peine forte et dure, czyli ,naciskanie do śmierci" ${ }^{22}$. Na unieruchomionego $w$ celi, $w$ pozycji leżącej oskarżonego, $z$ dnia na dzień nakładano coraz większy ciężar (kamienia, żelaza), doprowadzając w końcu do jego śmierci przez zmiażdżenie. Wybierając śmierć $w$ trakcie peine forte et dure, niektórzy $\mathrm{z}$ opornych oskarżonych ratowali tą drogą majątek dla swej rodziny. Ich śmierć uniemożliwiała bowiem zakończenie procesu, a co za tym idzie - orzeczenie konfiskaty majątku, niechybnie towarzyszące skazaniu za każde cięższe przestępstwo.

Świadom rysujących się tu niebezpieczeństw, Throckmorton nie zamierzał radykalnie odmówić ,zdania się na okolicę", nie omieszkał jednak skorzystać $\mathrm{z}$ okazji rozpoczęcia pewnej gry, którą konsekwentnie kontynuowal w dalszym

\footnotetext{
${ }^{20}$ Pope'a cytuje W. Gla nville, The proof of guilt. A study of the English criminal trial, London 1963, s. 11 (thumaczenie fragmentu poematu na polski - K.B.).

${ }^{21}$ State trials 1816, I, s. 870 i n., por. też C. G. L. Du Can n, English treason..., s. 70-71.

${ }^{22}$ Bliżej o peine forte et dure por. A source book of English law, ed. A. K. R. Kiralfy, London 1957, s. 18; I. H. Lang be in, Torture..., s. 76; J. Be11 a m y, Crime and public order in England in the later Middle Ages, London 1973, s. 138-139, 141-142.
} 
przebiegu trial. Polegała ona na zjednywaniu sobie przychylności grona przysięgłych, następnie zaś - stopniowym zasiewaniu w ich umysłach wątpliwości co do jego winy. Toteż miast zwykłej formuły: By God and my country, Throckmorton zareplikowal: By God and by faithful just men („Przez Boga i przez oddanych wierze, prawych ludzi”), zapewne - jak przypuszcza komentujący ten epizod Du Cann - zerkając przy tym w kierunku gremium przysięgłych ${ }^{23}$. Skład lawy pochodził z Londynu. Throckmorton wiedział zaś, iż w przeważającej większości mieszkańcy stolicy przeciwni byli małżeństwu królowej Marii z Filipem Hiszpańskim. Sąd, po krótkim wahaniu, zgodził się zaakceptować tak zmodyfikowaną odpowiedź „zdania się oskarżonego na okolicę" i proces potoczył się dalej.

Po przebrnięciu przez meandry pytań i odpowiedzi, przez które wchodziło się w angielski trial, oskarżyciele i oskarżony stali naprzeciw siebie w ,otwartym polu", gotowi do podjęcia kontradykcji. W angielskim procesie właśnie ten etap postępowania ważył o wszystkim. Bowiem owo zwarcie się stron, cross-examination świadków, spójność lub chaotyczność argumentacji oskarżonego - wszystko to kształtowało poglądy przysięgłych, którzy, przypomnijmy, przed wejściem na salę sądową, nie zapoznawali się $\mathrm{z}$ żadnymi aktami sprawy. Wysłuchiwali jedynie na początku trial treści wspomnianego już raportu mariańskiego, a więc sumarycznej informacji o sprawie wygotowanej przez sędziego pokoju, lub - w przypadku zbrodni politycznej - przez specjalną komisję śledczą.

Ten etap postępowania składał z kolei $\mathrm{w}$ ręce oskarżonego, jeśli okazał się on wystarczająco rzutki, duże możliwości ukształtowania obrazu sprawy w korzystnym dla siebie świetle. Oskarżony czynil to przez altercation. Altercation była wszelką interakcją między oskarżonym a oskarżycielem, lecz także między oskarżonym a świadkiem oskarżenia. W cytowanym już XVI-wiecznym fragmencie źródłowym Tomasz Smith opisuje przykład altercation: Po zaprzysiezzeniu [lawy - K. B.] - wywodzil uczony jurysta - sędzia zapytuje najpierw poszkodowanego, czy zna on więźnia $i$ każe mu nań spojrzeć. Ten zaś odpowie, iż go zna, czemu więzień czasem zaprzecza [...] I tak trwaja oni przez chwile w altercation. $W$ podobny sposób - pisał dalej Smith - mówiq po nim [tj. oskarżycielu - K. B.] ci, którzy byli przy pojmaniu więźnia lub ci, którzy mogq podać jakieś wskazówki lub znaki, które w naszym jezyku zwiemy dowodem oskarzenia ${ }^{24}$.

${ }^{23} \mathrm{~W}$ tym stadium postępowania przysięgli byli już ustaleni, czyniono to bowiem na początku trial. Tak oskarżyciel, jak i oskarżony mieli prawo z przedstawionej im listy przysiegłych wyrugowac nawet do 36 kandydatów, bez podawania uzasadnienia. Throckmorton nie wyrugował nikogo, schlebiając zaś ławie, nazwał jej członków „dobrymi chrześcijanami”, por. C. G. L. Du Cann, English treason..., s. 69-71. Na temat rugowania przysiegłych patrz K. B a r a n, Strony..., s. 73 i n.

${ }^{24} \mathrm{Th} . \mathrm{Smith}$, The commonwealth..., s. 185-186. 
Źródła wskazują, że w trakcie wszystkich tych wypowiedzi i przedkładania świadectw, oskarżony bezustannie mógł włączyć się ze swą interwencją przez altercation $^{25}$. Wreszcie mógł on wdać się $\mathrm{w}$ altercation $\mathrm{z}$ samym sędzią̧ ${ }^{26}$. W trakcie altercation oskarżony podważał wiarygodność świadków, podsuwał sądowi kontrowersyjną, lecz korzystną dla siebie interpretację przepisów prawa, stawial świadkom pytania krzyżowe, itp. Jakby na przedhżeniu altercation istniało prawo oskarżonego do kierowania pod adresem lawy komentarza na temat przebiegu rozprawy. Na gorąco mógł oskarżony dramatyzować $\mathrm{z}$ powodu - zgodnej skądinąd $\mathrm{z}$ ówczesnym zwyczajem prawnym - odmowy wysłuchania jego świadków obrony i ironizować na temat wiarygodności tych świadków oskarżenia, których sąd nie odważył się stawić z nim face to face na publicznej rozprawie. I choćby - wedle wyjaśnień sądu - roszczenia przezeń wysuwane przekraczały to, na co pozwalała ówczesna procedura, argumenty oskarżonego nie uchodzily przecież uwadze przysięgłych. Wszystkie zabiegi rzutkiego oskarżonego, włącznie $\mathrm{z}$ bezustannym komentowaniem przebiegu rozprawy, zlewały się w zespół czynników mających niewątpliwy wpływ na ostateczny werdykt ławy.

Przejdźmy teraz do dalszych szczegółów rozprawy Throckmortona. $\mathrm{Na}$ tym etapie winna ona, wedle zwykłej rutyny common law, rozpocząć się od wystąpienia oskarżycieli - owych prosecutors. Wszakże prawo oskarżonego do bezustannego interweniowania $w$ tok procesu było tak silne, że mimo wahań i oporów, sąd już na wstępie, jeszcze przed przesłuchaniem pierwszego świadka, ugiął się pod skierowanym przez Throckmortona żądaniem, by pozwolono mu wygłosić kilka słów (minded to say a few words). Zważmy zaś, iż padły wówczas słowa, które już na wstępie wyostrzyć miały uwage przysięgłych na wszelkie wątpliwości, tkwiące w wykładni pojęcia high treason. W owych pierwszych słowach Throckmorton apelowal do wieloosobowej ekipy doradców królewskich, którzy mieli go oskarżać, by nie uwiedli umyslów przysieglych, szczerych choć niećwiczonych $w$ prawie [...] Bo - dodawal - wiem, jak przez moc przekonywania, narzucania opinii, domniemania, aplikacje, insynuacje, wnioski, domysly, dedukowanie argumentów, przeinaczenia [...] ludzie nieobeznani mogq być zwiedzeni $w$ taki sposób, iżby myśleli i mniemali, że wielkq zbrodniq stanu sa rzeczy, które sq obojetne lub $w$ najgorszym wypadku stanowiq przeoczenie ${ }^{27}$. Przy okazji - dodawal oskarżony, cytując fragmenty $\mathrm{z}$ Biblii - na przewrotnie postępujących spocznie krew ich ofiar do trzeciego bądź czwartego pokolenia. Wypowiedź niewątpliwie wycelowana była na wywarcie odpowiedniego efektu na jurors.

${ }^{25} \mathrm{~J} . \mathrm{H}$. L a n g bein, Shaping the eighteen-century criminal trial. A view from the Ryder sources, The University of Chicago Law Review 1983, vol. 50, No 1, s. 124; W. F o r s y th, History of trial by jury, London MDCCCLII, s. 392-393; patrz też State trials 1810, VI, s. 884.

${ }^{26}$ Por. W. Forsyth, History..., s. 392; C. G. L. Du Cann, English treason..., s. 76 i n.

${ }^{27}$ Por. komentarz C. G. L. Du Canna, English treason..., s. 72. 
Istotną część rozprawy wypełnilo altercation między oskarżycielami ze strony Korony a oskarżonym bombardowanym przez tych pierwszych drobiazgowymi tezami zarzutów ze wspomnianym już: How sayeth thou... po każdym kolejnym punkcie. Inaczej niż w procesie pospolitym, gdzie sąd byłby skrępowany skromnymi materiałami raportu mariańskiego i gdzie na ogól sam sędzia przeprowadzałby cross-examination obwinionego, tu grupa fachowych sergeants dysponowała własnymi aktami ze skrupulatnie przeprowadzonego śledztwa, nierzadko odczytując tylko zeznania świadków oskarżenia, spośród których nie wszyscy zawezwani zostali na rozprawę. Ze względu na drobiazgowość, $z$ jaką oskarżyciele posuwali się punkt po punkcie przez kolejne tezy zarzutów, badanie przeprowadzane przez nich miało posmak inkwizycyjny, $\mathrm{z}$ tą istotną różnicą, iż następowało publicznie i ustnie w sądzie, i bez wywierania presji fizycznej na oskarżonego.

Zręcznym, błyskotliwym ripostom oskarżonego sergeants of the Crown musieli przeciwstawić skierowane przeciw niemu zeznania świadków. Tu wszakże okazało się, jak wielkie dobrodziejstwo plynąć mogło z odpowiednio spożytkowanego prawa oskarżonego do stawiania krzyżowych pytań, jak też jego interwencji wobec zeznań tylko odczytywanych na sali sądowej. Mógł oskarżony tym sposobem kompensować formalne niedostatki swego statusu. Mógł formować opinię ławy, podnosząc wyłaniające się z materiału dowodowego wątpliwości, świadom, iż te przez stronniczy sąd nigdy nie zostałyby w końcowym summing up zaakcentowane ${ }^{28}$.

Tak oto przykładowo, wówczas kiedy sergeants ograniczyli sie jedynie do odczytania serii zeznań świadków, Throckmorton przemyślnie nie protestował w takich razach, gdy chodziło o świadka dlań niebezpiecznego (jak np. Winter), którego zeznania - powtórzone na żywo w sądzie - mogły pozostawić głębokie wrażenie na przysięgłych ${ }^{29}$. Dramatycznie natomiast żądał Throckmorton zeznań viva voce w przypadku świadków stanowiących słabą stronę oskarżenia ${ }^{30}$. Sergeants stawali wówczas w obliczu bądź konieczności wystawienia tych świadków na cross-examination Throckmortona, co wiązało się wszakże z dużym ryzykiem, bądź zignorowania żądań oskarżonego, co z kolei wzbudzało uzasadnioną podejrzliwość ławy. Gdy więc mimo wezwań Throckmortona, nie stawiono wobec niego face to face świadka Croftsa, oskarżony mógł na oczach przysięgłych ironizować: Master Crofts is yet living and is here this day, how happeneth it he is not brought face to face to justify the matter? ${ }^{31} \mathrm{~W}$ innym momencie Throckmorton zdezawuowal istotne dla oskarżenia zeznania świadka Vaughana. Uczynił to przez zaadresowane do jury skomentowanie niskiego waloru tych zeznań. Vaughan

\footnotetext{
${ }^{28}$ W. F orsyth, History..., s. 393.

${ }^{29}$ Por. komentarz C. G. L. Du Cann a, English treason..., s. 73.

${ }^{30}$ Np. zeznania świadka Croftsa (por. ibidem, s. 75) lub Graya (ibidem, s. 77).

${ }^{31}$ State trials 1816 , I, s. 875 .
} 
- powiedział Throckmorton - był niewiarygodnym świadkiem, skoro już raz karany był sądownie ${ }^{32}$. Niegdyś w podobny sposób Tomasz More obnażyl słabość wymierzonych przeciw sobie zeznań świadka Richa - znanego w środowisku dworskim hazardzisty i łgarza ${ }^{33}$.

Również dzięki altercation z sergeants of the Crown mógł Throckmorton wychwycić nieuczciwość płynącą z posłużenia się przez nich dowodem typu hearsay, a więc $\mathrm{z}$ drugiej ręki. Okoliczność ta łatwo mogła ujść uwadze jury, jako iż w tej epoce - jak wspomniano wcześniej - reguła zakazująca hearsay nie była w pełni ugruntowana; rysowała się jednak na tyle wyraziście, iż można ją było spożytkować $w$ argumentacji przed sądem ${ }^{34}$. Opierając się na niej, Throckmorton zdezawuował zeznania księcia Suffolk, w gruncie rzeczy powtarzającego tylko to, co zasłyszał on od innego świadka - Lorda Greya. Dlaczego - zapytywał Throckmorton - nie wezwano do sądu samego Greya, by stanął on face to face z człowiekiem, którego oskarżal. W wyniku tak podniesionych zarzutów Korona - co znamienne - rychło porzuciła ten nurt oskarżenia ${ }^{35}$.

Throckmorton mógł wreszcie przez swą interwencję $\mathrm{i}$ adresowany do lawy komentarz skompensować choć w części godzące w niego archaizmy postępowania dowodowego. Chodziło o zakaz posługiwania się świadkiem obrony. Tak się złożyło, iż koronny świadek, mogący zeznać na korzyść oskarżonego, ukazał się przypadkowo na sali sądowej. Był nim Sir Fitzwillams. Sąd odrzucił jednak wniosek oskarżonego, by świadka tego przesłuchać, postępując zgodnie $\mathrm{z}$ ustaloną regułą zezwalającą $w$ tej epoce wyłącznie na świadków oskarżenia. $\mathrm{Ci}$ bowiem - jak powiedziano już wcześniej - mieli udowodnić oskarżonemu winę beyond reasonable doubt (poza zasięgiem racjonalnie nasuwających się wątpliwości). Świadkowie obrony wydawali się więc zbędni. Dzięki altercation mógł jednak oskarżony ową odmowe, $z$ jaką się spotkal, zdyskontować na swą korzyść. Zwracając się do jury, Throckmorton emfatycznie powiedział: Jako że oświadczenie tego dżentelmena [Fitzwilliamsa - K. B.] nie zostalo dopuszczone, ufam Waszmościom przysieglym, ze zechcq zauważyć, iż nie stalo sie to $z$ przyczyny, iżby musial on coś przeciw mnie zeznać, lecz przeciwnie, że obawiano sie, iż będzie na mq korzyść przemawia ${ }^{\natural 6}$.

Dynamika XVI-wiecznego prawa oskarżonego do altercation i interwencji była tak duża, iż - wbrew zwyczajowi - jeszcze po sędziowskim summing up

\footnotetext{
${ }^{32}$ Ibidem, s. 881; C. G. L. Du C a n n, English treason..., s. 76.

${ }^{33}$ Nie uratowało to wszakże życia More'a, por. komentarz C. G. L. Du Canna, English treason..., s. 51-52.

${ }^{34}$ I. H. B a ke r, Criminal courts..., s. 39; D. Ogg, England..., s. 102; W. G1anville, The proof..., s. 195. Bliższe naszym czasom podejście do hearsay omawia S. F. H a r r i s, Principles and practice of the criminal law, London 1943, s. 482.

${ }^{35}$ Komentarz C. G. L. Du Can n a, English treason..., s. 77.

${ }^{36}$ State trials 1816 , I, s. 885 i 887-888; C. G. L. Du Ca n n, English treason..., s. 76.
} 
Throckmorton wymusil na sędziach pozwolenie na swą ostateczną wypowiedź adresowaną do jury. Nie omieszkał w niej ostrzec przysięgłych przed zgubnymi dla chrześcijańskiej duszy skutkami orzekania w sposób stronniczy ${ }^{37}$ Narada lawy zakończyła się uniewinnieniem Throckmortona.

Można mniemać, iż błyskotliwy oskarżony w podobny sposób nieraz ratował gardło i w procesie pospolitym. Potwierdza to opis Smitha, akcentujący, iż strony trwały nieraz $w$ długiej zapewne altercation. W przeciwieństwie wszakże do procesów politycznych, które ze względu na rozgłos odnotowywane były przez współczesnych $z$ dużą skrupulatnością $w$ ich prywatnych zapiskach, procesy pospolite - odwrotnie: wobec znamiennego dla prawa Anglii braku zwyczaju protokołowania rozprawy - nie pozostawiły podobnych śladów źródłowych. Jeśli jednak posłużyć się analogią z czasów późniejszych, gdy materiały na temat procesów pospolitych są obfitsze, można przyjąć, iż zręczny oskarżony mógł i w czasach wcześniejszych skutecznie wpływać na werdykt lawy ${ }^{38}$.

4. Śledząc rozprawę Throckmortona, latwo skonstatować, iż w rzeczywistości ocena ograniczeń i dobrodziejstw, które składały się na dawny angielski proces, może być nader złożona. Proces Throckmortona, mimo wszystkich ograniczeń trafiających $\mathrm{w}$ oskarżonego, wlaśnie przez przysługującą mu altercation wydobył znienacka niezwykłe dlań dobrodziejstwa. Pozwalal oskarżonemu wręcz zdyskontować na swą korzyść także i owe godzące w zasadzie w niego niedostatki procedury. Inna rzecz, że czerpanie tych korzyści dostępne było tylko dla oskarżonego o niezwykłej energii $\mathrm{i}$ inteligencji ${ }^{39}$. To, co czynil Throckmorton poprzez altercation, stanowiło finezyjną gre polegającą na ostrej reakcji wobec zarzutów, które obiektywnie latwe były przezeń do zbicia, przemyślnym zaś tuszowaniu wydźwięku dowodów, które mogły go pogrążyć w oczach lawy. Jak widzieliśmy, w paradoksalny sposób nawet brak słuchania niektórych świadków viva voce $\mathrm{w}$ sądzie obracal się na korzyść oskarżonego, poprzez jego komentarze adresowane do lawy.

${ }^{37}$ C. G. L. Du Cann, English treason..., s. 80.

${ }^{36}$ Z późniejszych czasów warto choćby odnotować casus Barringtona - ewidentnego przestepcy, który swe kolejne uniewinnienia zawdzięczał zxęcznej altercation i przemożnemu wpływowi, jaki wywierał na jury przez przeprowadzane cross-examination i mowy adresowane do przysiegłych, $\mathrm{Ch}$. Joh $\mathrm{ns}$ on, The history of the lives and actions of the famous highwaymen, streetrobbers, etc, to which is added a genuine account of the voyages and plunders of the most noted pirates, Edinburgh 1813, s. 507 i n. Na temat Barringtona por. też Dictionary of national biography, vol. I, s. 1208-1209.

${ }^{39}$ K. B a r a n, Strony..., s. 99. 
Du Cann wyraża opinię, iż tylko dzięki przytomności umysłu i zręcznej strategii Throckmorton uratował gardło ${ }^{40}$. Powiedzmy bardziej precyzyjnie: Throckmorton zawdzięczał życie skuteczności własnej altercation. Przykład Throckmortona potwierdzal, iż glówną niedolą oskarżonego w dawnym angielskim procesie karnym był zakaz posługiwania się przezeń obroncą w każdej poważniejszej sprawie. Nie każdy podsądny był bowiem w stanie samodzielnie sprostać wyzwaniom, jakie stawiała przed nim rozprawa sądowa.

Dodajmy na koniec, iż przysięgli, którzy uwolnili Throckmortona, wylądowali bezpośrednio potem $w$ Tower lub Fleet i przetrzymywani byli w więzieniu do końca roku. Potem zwolniono ich po zapłaceniu przez nich grzywny. Także i Throckmorton, mimo iż oficjalnie uniewinniony przez lawe, byl przez czas pewien przetrzymywany w Tower. Pod panowaniem natomiast Elżbiety Wielkiej kontynuowal swą karierę polityczną ${ }^{41}$.

${ }^{40}$ C. G. L. Du Ca n n, English treason..., s. 67-77.

${ }^{41}$ State trials 1816, I, s. 900-902; C. G. L. Du Ca n n, English treason..., s. 82-83; Dictionary of national biography, vol. XIX, s. 810-814. 